\title{
How European Union policy actors use and assess the effectiveness of e-transparency
}

Mark Field

\begin{abstract}
To counter the charge that it is an elite-driven political project, the European Union increasingly uses online systems to render its working practices visible to its citizens. This article analyses how the actors involved in European Union policy-making understand the benefits derived from providing information through e-transparency, and examines whether they consider that the e-transparency systems deliver these benefits. Drawing on data from 63 semi-structured interviews with officials, Members of the European Parliament and Brusselsbased transparency campaigners, the article shows a wide variation in participants' views concerning the rationale for e-transparency. It shows that e-transparency is variously seen as the means to address declining citizen trust in the Brussels institutions; as a mechanism through which citizens can participate in European Union processes and as a means of holding its institutions to account. The article argues that these various e-transparency attributes are contradictory, and it advances a framework for information providers to assess how the etransparency tools can best meet the differing requirements of transparency users.
\end{abstract}

\section{Keywords}

Accountability citizen participation e-government transparency trust 


\section{How European Union policy actors use and assess the effectiveness of e-transparency}

In a speech to the European Parliament (EP) in May 2016, Commission Vice President Timmermans stated that 'Transparency is one of the few tools we have to reconnect with citizens who are sceptical of our legislature'. Whilst a growing antipathy towards mainstream politics is not peculiar to the European Union (EU), Timmermans' statement speaks to the particular challenge of countering the EU's public image as an elite-driven political project ${ }^{1}$.

To mitigate the charge that the EU is too remote, it increasingly uses online systems to render its working practices visible to its citizens. There is not, however, a single model of etransparency, with different EU institutions having varying and sometimes contradictory logics for using e-transparency to reconnect with the public. This paper explains how different groups of EU policy actors understand the benefits derived from providing information through etransparency systems and examines whether they consider the e-transparency tools to be effective in delivering these benefits. Using data drawn from 63 semi-structured interviews with Members of the European Parliament (MEPs), officials from the EU institutions and representatives of transparency advocacy groups, this article reveals clear differences between the rationale for e-transparency between elected representatives, unelected officials and campaigners. By considering and explaining how e-transparency is intended to serve multiple purposes, the article adds to the relatively small but growing body of empirical transparency studies (Douglas and Meijer, 2016; Grimmelikhuijsen et al., 2013) and contributes to the wider discourse about the functioning of e-government (Ionescu, 2015; Welch, 2012).

The article proceeds as follows. The first section shows that scholars define and conceptualise transparency and e-transparency in different ways, and identifies the overlaps between the literature on transparency in general and e-transparency in particular. The second section explains the paper's data gathering approach before section three describes the research 
findings. Section four discusses the implications of the distinct differences amongst policy actors concerning the purpose and effectiveness of e-transparency. Overall, the article shows that e-transparency is used by different actors and groups to serve different purposes and that, in effect, this leads to multiple transparencies that can create a complex and often contradictory transparency picture.

Whilst there is growing academic interest in EU transparency, the ongoing financial crisis has provided the backdrop for recent work, most of which has explored transparency in the context of the EU's corporate and financial sectors (Bellenca and Vandernoot, 2014; Horvath and Vasko, 2016). This article focuses instead on transparency as it is practiced in the public realm. Before considering these perspectives in detail, however, the article considers how the terms transparency, e-transparency and effectiveness are defined and conceptualised.

\section{Defining and conceptualising transparency and e-transparency}

\section{Transparency}

Academic definitions of transparency tend to focus on either its process or purpose, although with some overlap. For the former, the emphasis is on the degree to which an organisation makes explicit information concerning aspects such as its decision-making processes, performance and procedures (Curtin and Meijer, 2006; Welch et al., 2005). Welch et al., for example, define transparency as 'the availability of information for navigating a large-scale social system' (2005, p. 378). For this article - with its emphasis on transparency as it is understood by those involved - this approach is rather limiting, as its focus is on measuring the provision of information, rather than the rationale for providing the information in the first place. An alternative approach considers transparency in purposive terms. This often views transparency as a means of exercising discipline over institutions and office holders by making information about their performance public and thus deterring corrupt practices and poor 
performance (O'Neill, in Etzioni, 2010, p.393). This stress on countering malpractice is also reflected in Hood's work on the relationship between transparency and governance which defines transparency as 'Government according to fixed and published rules, on the basis of information and procedures that are accessible to the public' (Hood, 2006, p.701).

Although it is broader in meaning than that offered by Welch et al, for this article Hood's definition is also found wanting. Both Hood and Welch et al. focus on the top down provision of information, but neither captures the practical elements that render transparency practicable, such as the specificity of the measures needed to ensure accessibility of information. Neither is the EU's own definition sufficient for this paper, largely because there is no single EU definition of transparency. Rather, each institution has its own definition based on institutional function. The Commission, for example, refers to transparency as 'The right of citizens to know how European institutions prepare decisions, who participates in preparing them, who receives funding from the EU budget, and what documents are held or produced to prepare and adopt the legal acts' (European Commission, 2016). The European Parliament's definition is rather more tightly drawn, referring to transparency as a means for '...facilitating citize ns' scrutiny over Parliament's activities and, in particular, its legislative work' (European Parliament, 2017), whilst the Court of Auditors states that transparency is a means for 'disclosing information about our management and activities, and publishing the results of our audit work' (European Court of Auditors, 2017).

Definitions used by other transparency providers are also rather narrowly circumscribed. For example, the first report of the British Committee on Standards in Public Life simply refers to '...holders of public office [being] as open a possible about all the decisions and actions they take' (Nolan, 1995, p.14). Notably, however, the same committee later broadened the scope of this definition, with its most recent iteration published on the British Government website: 'Transparency is not just about access to data, but also making sure that it is released in an 
open, reusable format' (HM Government, 2016). Here the committee's definition marks a change of tone from transparency as an overarching principle intended to guide policymakers towards transparency as a set of practical measures delivered by online processes: a shift from transparency to e-transparency.

\section{E-transparency}

The increase in the provision of information on EU processes has mirrored technological developments, with recent transparency innovations employing exclusively online processes. This move towards online transparency has, unsurprisingly, reflected the rapid growth in internet access: under $10 \%$ of EU citizens had access to the internet in 2000 against over 90\% in 2016 (Eurostat, 2016). This shift towards transparency provided through online systems has a number of labels, including 'computer-mediated transparency' (Meijer, 2009) and ICTenabled transparency (Bannister and Connolly, 2012). For consistency, this article uses the term e-transparency throughout.

For Railine (2015), e-transparency has all the characteristics of general transparency but delivered using information and communication technology (ICT). Nonetheless, scholarly definitions of e-transparency have tended to focus on specific aspects. It follows that, so far as practicable, a definition of e-transparency should try to capture these different traits. By synthesising scholarship, the information provided through e-transparency tools can be assessed not just in terms of its completeness (Drew and Nyerges, 2004), but also usability (Mahler and Regan, 2007) and accuracy (Jaeger and Bertot, 2010). In addition, Heald (2006) distinguishes between information being made available in real time and retrospectively, and Héritier (2003) emphasises the importance of public accessibility to information. By combining the features covered in the wider academic literature, a reasonably comprehensive set of criteria can be established in order to provide a suitable definition of e-transparency for 
this article. Table 1 summarises the main features of transparency identified in the academic literature applying them to the EU's e-transparency tools.

Table 1. Features of e-transparency.

\begin{tabular}{|l|l|l|}
\hline Feature: & Associated with: & Operationalised as: \\
\hline Accuracy & $\begin{array}{l}\text { Jaeger and Bertot, } \\
\text { 2010. }\end{array}$ & $\begin{array}{l}\text { Does e-transparency provide user with } \\
\text { factually correct information? }\end{array}$ \\
\hline Completeness & $\begin{array}{l}\text { Drew and Nyerges, } \\
\text { 2004. }\end{array}$ & $\begin{array}{l}\text { Does e-transparency provide user with } \\
\text { al relevant information without } \\
\text { omissions? }\end{array}$ \\
\hline Accessibility & Héritier, 2003. & $\begin{array}{l}\text { Does e-transparency have multiple } \\
\text { access points? Can a non-specialis t } \\
\text { easily navigate the online systems? }\end{array}$ \\
\hline Timeliness & Heald, 2006. & $\begin{array}{l}\text { Is e-transparency provided in real time or } \\
\text { retrospectively? If the latter, is delay for } \\
\text { operational reasons? }\end{array}$ \\
\hline Usability & Mahler and Regan, & $\begin{array}{l}\text { Does e-transparency } \\
\text { information in an accessible format (e.g. } \\
\text { in multiple languages/in a searchable } \\
\text { form). }\end{array}$ \\
\hline
\end{tabular}

This article therefore advances a tailored definition of the EU's e-transparency processes that captures the features at table 1 . Thus, for this article, e-transparency is defined as: Online access to timely, complete, usable and accurate information on the EU policy process.

Conceptually, e-transparency relates to broader issues of e-government and e-democracy. Egovernment refers to the use of technology tools to provide government services and information (Welch et al., 2005), whilst e-democracy refers to the use of technology tools to allow citizens to participate in governance (Bannister and Connolly, 2012). The EU's etransparency serves both purposes: it provides public access to information and serves as a channel through which the public can participate in the decision-making process. 
In their wide-ranging review of transparency research, Porumbescu and Grimmelikhuijsen (2016) identified a marked increase from around 2005 of the publication of public administration articles focusing on transparency. However, most of this work has analysed transparency as an independent variable, using it to explain a variety of outcomes including trust, participation and accountability. Park and Blenkinsopp (2011), for example, characterise transparency as an independent variable in the corruption-trust relationship, whilst Curtin and Meijer (2006) portray it as a linking mechanism between policy making and input legitimacy. Indeed, with such a breadth of outcomes, the 'complex dynamics of transparency' (Meijer, 2012) cut across academic disciplines with scholars variously analysing transparency as a driver of EU accountability (Brandsma and Schillemans, 2013: Fox, 2010); trust (Grimmelikhuijsen et al., 2013); participation (Harrison and Sayogo, 2014); legitimacy (Curtin and Meijer, 2006; Meijer, 2012); democracy (Schmidt, 2013; Heald, 2006) and good governance (Hood, 2006). This article does not directly consider e-transparency's links to these associated concepts, rather it seeks to explain the views of those involved in the EU policy process concerning the purpose and perceived effectiveness of e-transparency.

\section{Effectiveness of e-transparency}

Understanding the extent to which e-transparency is effective is, of course, complex, and would normally invite a framework through which the effectiveness can be assessed. For this study, however, different groups of actors view transparency as having varying purposes, so identifying a single measure that captures the effectiveness of e-transparency is problematic. For example, the criteria for assessing the effectiveness of e-transparency in facilitating institutional accountability would differ from the criteria seeking to assess the effectiveness of transparency as a driver of public participation. To accommodate these different criteria, this article uses the term effectiveness to describe: the extent to which the e-transparency tools deliver their perceived benefits. 


\section{Data gathering approach}

Before undertaking interviews with those involved in the policy process, it was necessary to have an initial understanding of the EU's stated rationale for providing information through online transparency tools. To achieve this, a textual analysis of a sample of transparencyrelated documentation was undertaken. In order to manage a large number of documents, only those published during or after the Barroso Commission were included in the initial search. Whilst it was recognised that this would exclude some important transparency documents such as the 2001 White Paper on Governance, and Regulation 1049/2001 on Public Access to Documents, it was considered that taking the Barroso Commission's 2005 launch of the European Transparency Initiative (ETI) as a starting point was justified, given the importance of the ETI as a transparency milestone and given that it was unlikely that earlier documents would have directly affected interview participants.

To identify relevant documents, two databases were searched: the European Parliament's Register of Documents and the Register of European Commission Documents. Document search criteria included reference to the terms 'EU transparency';

'Parliament/Commission/Institutional transparency' or 'European Transparency Initiative' in the title and a publication date after 1 Jan 2005. The searches yielded 83 and 59 documents respectively. Using the databases' own algorithms to sort the documents by relevance, the top 15 per-cent of documents from each database was examined $(n=21)$. The documents included, but were not limited to, those relating to the ETI, including a transcript of Commissioner Kallas' Nottingham speech; the original ETI Green Paper; ETI-related press releases and documents pertinent to the public consultation. The document analysis mapped instances of official EU documents using terms commonly found in the transparency literature including participation, democracy, accountability and legitimacy. These terms were used to create the typology for the themes emerging from analysis of the interview 
transcription. To illustrate, analysis of the ETI Green Paper shows transparency most frequently linked to participation (8 instances), then accountability (7) and legitimacy (6), but shows little linkage between transparency and anti-corruption (1).

To identify interview participants, the EP website was used to break down the membership of those committees likely to have a particular interest in transparency. These included the Constitutional Affairs Committee; the Petitions Committee and the Civil Liberties, Justice and Home Affairs Committee, with priority given to targeting the Chair, Rapporteur and Shadow Rapporteur of these committees. To identify relevant Commission officials, transparency advocates were asked to identify officials and Directorates with whom they had most dealings as this was considered a strong indicator of an interest in transparency issues ${ }^{2}$.

In total, 63 semi-structured elite interviews were conducted between March 2013 and February 2014 with Commission and EP Officials, MEPs and transparency campaigners. MEPs were drawn from across political groupings and EU member states (MS). Commission officials represented six different Directorates-General. The majority of transparency groups involved in this research are Brussels-based, although interviews were also conducted with transparency groups based in Spain, The Netherlands and the United Kingdom.

At the start of each interview, participants were informed that the context of the research project was an analysis of the rationale for and the effectiveness of the various online processes introduced to increase the transparency of EU policy making. Interview questions initially investigated participant's views around EU transparency in general, before examining their attitudes to e-transparency in particular. The transparency coding scheme at Table 2 was used to assign responses to one or more of the linked themes explored in the transparency literature and these linked themes were used as indicators for the purpose of transparency. 
Table 2. Transparency coding scheme.

\begin{tabular}{|l|l|}
\hline $\begin{array}{l}\text { Transparency's linked } \\
\text { themes }\end{array}$ & Associated with \\
\hline $\begin{array}{l}\text { Transparency and } \\
\text { Accountability }\end{array}$ & Brandsma et al., 2016; Fox, 2010 \\
\hline Transparency and Democracy & Heald, 2006, Schmidt, 2013. \\
\hline Transparency and Governance & Hood, 2006 \\
\hline Transparency and Legitimacy & Curtin and Meijer, 2006; Meijer, 2012 \\
\hline Transparency and Participation & Harrison and Sayogo, 2014 \\
\hline Transparency and Trust & Grimmelikhuijsen et al., 2013 \\
\hline
\end{tabular}

Interview transcripts were analysed in order to reveal whether, and to what extent, the linking themes established in the document analysis and the academic literature and summarised at Table 2 were cited by those closely engaged with the policy process.

Where the exact term was not used, responses were allocated to the function closest in meaning. For example, the term 'citizen engagement' was assigned to 'participation' and 'increased confidence' to 'trust'.

\section{Findings}

Amongst all participants, trust and accountability were the most frequently cited linking themes when considering the purpose of transparency. However, more granular analysis of the interview data revealed clear differences in the rationale for e-transparency according to actor type. This can, of course, be partly attributed to the different numbers and varying lengths of the interviews conducted with participants from each group. More significant for this study is the relative importance of the various purposes attributed by each actor type. This is depicted at Figure 1 below. 
Figure 1. Purpose of e-transparency by actor type.

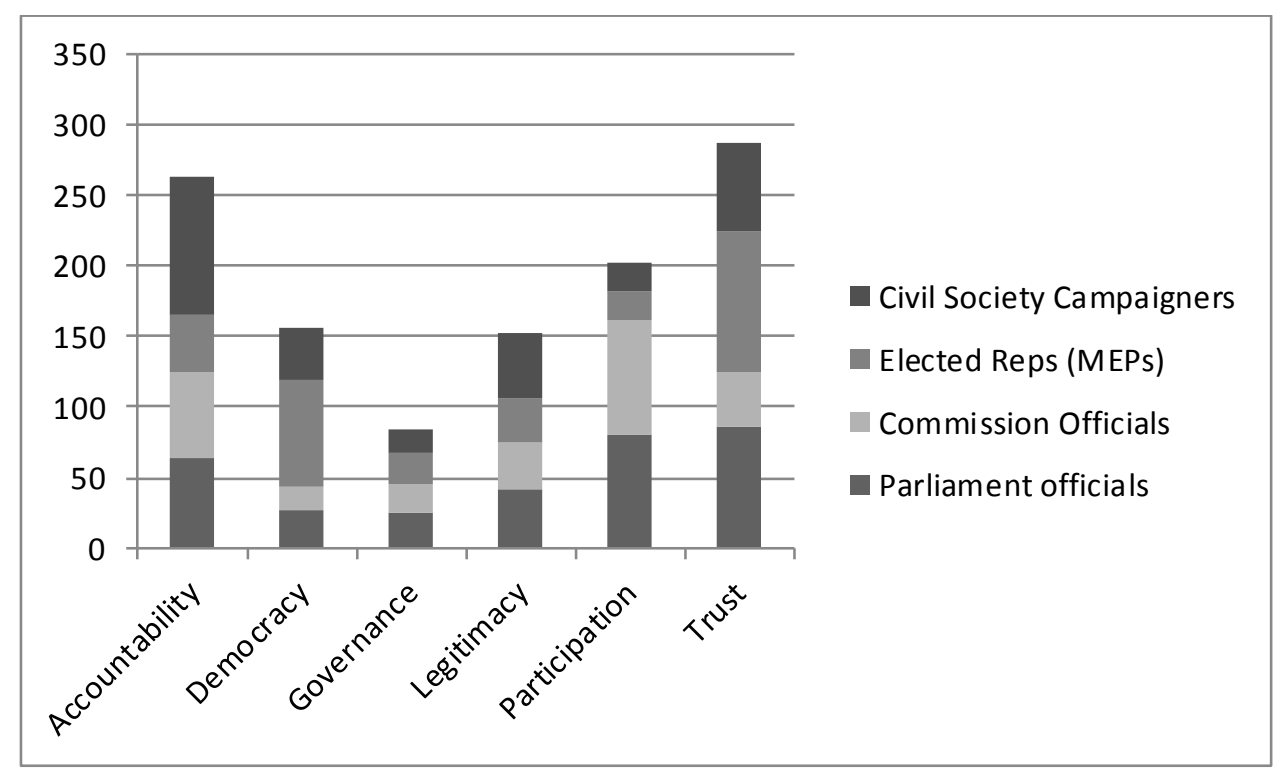

As Figure 1 shows, MEPs used terms associated with trust most frequently, whilst Commission Officials more often referred to participation. Conversely, campaigning groups focussed chiefly on e-transparency's links to accountability, with a particular stress on its function in ensuring that the Commission is held accountable. The next section explores these groups' different views as to the purpose of e-transparency in more depth.

\section{European Commission and European Parliament officials}

It was clear that e-transparency's links to participation were prevalent amongst unelected officials at both the EP and the Commission. Commission officials, in particular, viewed etransparency as a means of enhancing opportunities for citizens to engage in the policy process. A number specifically referred to various online tools associated with the European Citizens' Initiative (ECI) as an example of an innovative e-transparency tool. In particular, three officials singled out the online transparency portal on the Europa website as an example of the Commission's commitment to transparency in general and to e-transparency in particular.

Beyond its perceived role in enhancing citizen participation, some officials also stated that the Commission uses e-transparency as a means of increasing its legitimacy by providing greater 
access opportunities for EU citizens. It is not clear, however, how this increased legitimacy operates, given that a relatively small proportion of citizens make use of these greater access opportunities; a point tacitly acknowledged in one official's observation:

It's completely underestimated, the level of transparency...you can see all the forms...you can follow all the debates from your home, if you want to. But hardly anyone does, in practice, which is not surprising. I think [for most people] the newspaper is enough. ${ }^{3}$

Another participant echoed this view but also acknowledged that the transparency mechanis ms are used by specialists, whilst another took the view that the degree of transparency of the EU policy processes compared favourably against policy transparency in some MSs:

I think the decision-making process is very transparent. You can follow the legislative process...and this is used by organised civil society, by interest groups...far more than by the public, and it is not, unfortunately, always used by the media. ${ }^{4}$

The EU has a very transparent process. You can follow the legislative process, access all the documents from you home. I do not find the same level of transparency in my government in [EU MS]. The transparency here is far stronger than in most member states. The people are able to see how open is the process in the EU. ${ }^{5}$

When considering recent measures taken by the Commission to increase e-transparency, five officials singled out the Europa website. Claiming to be 'one of the largest sources of information in the world' (Europa, 2016), the Europa portal contains over six million pages and receives 1.7 million visits each month, although it should be noted that the system captures 
data for each unique visit rather than unique visitors, meaning that multiple visits by the same individual are counted separately (Europa, 2016) ${ }^{6}$. Nonetheless, Europa acts as a single access point which provides multiple links to the institutions' websites and to facilities such as Europarl TV - discussed below. Additionally, Europa has hosted a dedicated transparency portal since 2011. Although this portal does not provide any new transparency systems, it allows users to link to pre-existing e-transparency tools from a single access point. Thus, through the transparency portal, users can access most of the EU's searchable databases, its public consultations, Commission impact assessments, the online registers and so forth. Interestingly, Commission officials identified this portal as a transparency gain for organised groups, rather than EU citizens:

We have the transparency portal. It's just a one stop shop to find all the other portals but from here you can see all aspects of transparency...even the beneficiaries of EU funds...it allows the media or civil society to compare the declared policy objective to the reality. And, of course, these groups use the portal to further their campaigns - to create dissatisfaction, if you like. ${ }^{7}$

When asked to comment on whether they considered the e-transparency tools to be effective in delivering an increase in citizen participation, Commission officials seemed resigned to the situation where the transparency tools are chiefly used by societal and campaigning groups rather than individuals:

Of course, the average citizen does not look at [the transparency register], but that is not the real problem. The real problem is that people do not know the information is available to them. So they just think the EU is secretive. ${ }^{8}$

Nonetheless, despite its apparent acknowledgement that there is limited demand for information about EU processes from its citizens, the Commission continues to promote and 
prioritise transparency as a means of increasing EU legitimacy and citizen participation. For the EU's elected representatives, however, the rationale was quite different, with the emphasis instead placed on transparency's links to trust or related terms.

\section{Members of the European Parliament}

MEPs from across political groupings and of different nationalities shared a view that etransparency played a critical role in enhancing trust in the institutions, with four citing the example of the MEP's online Register of Interest as evidence of the EP's commitment to greater transparency. Several MEPs specifically referred, in this context, to 'rebuilding trust', a phrase that alludes to the 2011 'cash for amendments' story published by the Sunday Times. On this issue, some MEPs displayed a considerable level of unease and sensitivity - even defensiveness - when discussing the link between transparency and trust in the EP. This sensitivity may explain the responses to the interviews' seemingly innocuous initial question which asked interviewees to explain the purpose of transparency. Two such responses are quoted in full below:

We have to be transparent because we do an important job and we work hard. We work hard for citizens and we try to engage with them. And of course, we want them to engage with us. The Sunday Times approached many of us, you know? And they only found three...of course that is three too many....but only three. But of course they [the Sunday Times] don't tell you that. ${ }^{9}$

Transparency is vital. It's about trust...in the institutions... in the processes. We have rules here...we have regulations and codes of conduct...and most of us understand these. But the public don't understand these - they just read the newspapers...they see the Sunday Times and think "they are all like this". Transparency is how we show them we're not. ${ }^{10}$ 
In the context of a series of questions relating to Eurobarometer data on trust in the EU, some MEPs remarked that the EP consistently polls as being the most open of the institutions, again citing Europarl TV as evidence of this. Uniquely amongst the EU institutions, the EP broadcasts much of its activity in real time on Europarl. An online streaming service, rather than a conventional television station, Europarl was launched in 2008 and broadcasts EP sessions and Committee hearings live, in addition to educational programmes, debates and interviews with MEPs and commentators. Although created by the EP, the running of Europarl TV is actually outsourced to a production company with independent journalists presenting its programmes. Interviewees were asked their opinion as to the value of Europarl TV as a transparency tool. Whilst most MEPs felt that the facility makes a positive transparency contribution by providing information to EU citizens, a number also stated that its low viewing figures limited its use as an information provider:

It has opened up the process for sure, although nobody can claim it's watched by millions. But, then again, it isn't a private channel living by the size of its audience. $^{11}$

A small proportion of EP interviewees had a negative view of the Europarl streaming platform, generally with reference to its $€ 9$ million running costs. One response, in particular, suggested that the debate around the introduction of Europarl TV was highly charged and somewhat politically divisive:

They [The European People's Party] don't like it [Europarl TV] and say that it's all propaganda but that's because they have their own version. Great, but if you want to see bloody propaganda watch EPP TV, which talks about debates in the $\mathrm{EP}$ as if there were only EPP members. ${ }^{12}$ 
Whilst the quotation above seems to indicate a significant level of political sensitivity around the introduction of Europarl TV, the streaming service was often cited by MEPs as evidence that the EP has a greater commitment to e-transparency than the Commission:

We have this Europarl TV now. People can see what goes on in this place [EP]. They can watch the committees, the plenary...all the proceedings. People can see most of our work, if they want to. Very few people watch, of course, but they can. That's the difference between us and the Commission. The Commission has its committees closed off...there is no public access. Ours are in the public view - we have nothing to hide. ${ }^{13}$

In this response, it is clear that this MEP sees the purpose of Europarl TV as a means of building trust in the EP by providing a window on the EP's activities whilst also enhancing the EP's transparency credentials vis a vis the Commission. When MEPs were asked to comment on whether they considered the e-transparency tools to be effective in increasing citizen trust in the EP, there was a recognition that few private citizens actually access the information provided through the EP's e-transparency tools:

Well, the [European Parliament] website is effective for those that use it, I suppose. But it is mostly used by campaigners and journalists looking for a story, and the way they report things does not really increase trust. So transparency serves interested parties, for the most part. Citizens do not know about the information available to them. ${ }^{14}$

For those operating within the EU institutions - elected representatives and officials - trust and participation were cited as the main purposes of the e-transparency processes. Participants from these groups made little mention of a link to accountability: an aspect of particular interest to campaigning groups. 


\section{Campaigning groups}

A number of Brussels-based campaigning groups have areas of activity which particularly focus on the corporate sector. These groups promote EU transparency as a means of achieving a wider campaigning end: that is, transparency is its extraneous aim. To illustrate, the European Coalition for Corporate Justice (ECCJ) campaigns for tighter regulation on financial disclosure by multi-national companies (ECCJ, 2016) and uses the EU's transparency tools to identify instances of multi-national company (MNC) representation on the EU advisory committees ${ }^{15}$. In this regards, ECCJ is fairly typical of societal groups. It campaigns for greater transparency of EU policy-making insofar as this helps it scrutinise corporate involvement in financial regulation. Similarly, the campaigning group Friends of the Earth Europe (FoEE) advocates greater EU transparency as this supports the gathering of data to aid the delivery of core projects such as its bio-diversity and climate justice programmes.

Other groups, however, have EU transparency as an intrinsic aim: it is not used as a means to further a wider campaigning objective, but as an end in itself. Here EU transparency is used to monitor and publicise the relationship between the EU institutions - particularly the Commission - and the corporate sector across a range of policy areas. For example, the Brussels-based group Corporate Europe Observatory (CEO) and a closely related group the Alliance for Lobbying Transparency and Ethics (ALTER-EU) are well established transparency campaigners and both are adept at using the EU's own transparency processes to identify and publicise instances of meetings or informal contacts between Commission officials and individuals from the corporate sector. Indeed, this is the groups' raison d' etre with ALTER-EU's stated role as representing members 'concerned with the increasing influence exerted by corporate lobbyists on the political agenda in Europe' (ALTER-EU, 2016). Similarly, CEO's logo includes a strapline 'Exposing the power of corporate lobbying in the EU' (CEO, 2016). In the conduct of their operations, both groups adopt a dual role in 
monitoring and publicising the relationship between the institutions and corporate bodies. As such, it is perhaps unsurprising that interviewees from societal groups cited accountability as the principal function of EU transparency.

Transparency is what we do - it is how we hold the [EU] bodies accountable.

That's true for us and it's true for other groups like us. We all use transparency to watch them [the EU institutions] and to expose the links between the Commission and big business. ${ }^{16}$

This closeness between corporate and institutional actors was a frequently recurring theme in interviews with members of societal groups. Indeed, some participants from these groups acknowledged the paradox whereby they use data obtained from the EU's own transparency tools to identify and publicise instances of a supposedly opaque relationship between the institutions and the corporate sector.

Well, it is true that a lot of information in our reports comes from analysing the [EU's] websites. But we identify unhealthy relationships and we raise the profile in public. Few citizens access these websites, so we do this for them. We hold the Commission to account for the public. ${ }^{17}$

In this response, the transparency group's representative recognised the limited extent to which the transparency tools are used by individual EU citizens and openly stated that the group acts as a proxy for public scrutiny. In terms of assessing the effectiveness of e-transparency measures, the same participant suggested that that the quality and extent of the group's scrutiny was affected by the accuracy of the information provided through the e-transparency tools.

We need accurate data if we are able to properly hold [the Commission] to account for the public. Of course, most of that data is supplied by the Commission itself. 
We check the accuracy as much as we can, but we are a small group, you know?

So you could say that our ability to hold the Commission to account depends on the quality of the information the Commission publishes. ${ }^{18}$

For societal groups, then, e-transparency provides the means for them to monitor the relationship between the institutions and corporate bodies, rather than a mechanism to allow the activities of the transparency advocates to be observed by outsiders:

So for us, transparency is a tool to expose excessive influence by very small minority groups like corporate leaders... it allows us to scrutinise activity and to document and publicise one sided decision-making. ${ }^{19}$

With their emphasis on monitoring the institutions, it is perhaps unsurprising that interview participants from societal groups overwhelmingly privileged the role of transparency in enhancing accountability. It was, however, striking that these individuals characterised the role of their groups as acting as a proxy for the public and that they systematically use the EU's own transparency processes to monitor and publicise the relationship between the Commission and the corporate sector.

\section{Discussion}

In terms of the views as to the primary purpose of e-transparency, the distinction between unelected officials and elected representatives was clear, as was the marked difference between the views of those operating inside the institutions and those campaigning from outside. Officials at both the EP and Commission took a view that the degree of transparency of the legislative process compares favourably to that in some MSs. This suggests that it is only by direct comparison with the situation in MSs that enhanced EU e-transparency tools can lead to legitimacy gains. Commission officials tended to assume a link between e-transparency and 
the EU's legitimacy, although the linking mechanisms were not clear. In Curtin and Meijer's exploration of the linkages between these ideas, they suggest that greater transparency leads to social acceptance of the policymaking structures and that this - in turn - leads to greater input legitimacy (Scharpf, 2009; Curtin and Meijer, 2006). For e-transparency, however, this social acceptance will only occur if there is a public appetite for utilising the transparency tools in the first place. Expressed more simply, using e-transparency tools to increase the public visibility of EU processes will not lead to legitimacy gains unless there is sufficient public interest in the processes in the first place. Indeed, by focussing chiefly on the provision of legislative transparency - often technical and requiring some understanding of the EU's institutional workings - the e-transparency mechanisms may actually deter engagement by the nonspecialist, invalidating the intended legitimacy gains.

Several Commission officials suggested that the availability of information through the etransparency mechanisms is evidence of an open process. In advancing the European Citizen's Initiative as an example of innovative transparency, Commission officials cited an example of an online tool designed to provide an access point for citizen engagement. This supports the case that, for the Commission, the main purpose of e-transparency is to facilitate participation. However, whilst it is acknowledged that the ECI is a novel and imaginative means of facilitating transnational participation, as a transparency tool, its use is limited. It serves the Commission's participatory function of e-transparency by providing access to the views of those citizens who choose to participate, but it does nothing to allow the citizens to observe the conduct of activities within the institution: the accountability function.

In terms of the transparency portal hosted on the Europa website, Commission officials acknowledge it does not add any new transparency systems, rather it acts as a 'one stop shop', allowing users to view pre-existing e-transparency tools from a single access point. As such, 
evaluating the impact of this portal illustrates the difficulty of trying to capture the effectiveness of e-transparency systems through a single conceptual lens.

It was striking how often MEPs favourably compared the EP's e-transparency processes to those at the Commission. This would seem to indicate that, despite an increase in both formal and informal ties operating at the institutional level (Egeberg et al., 2014), some interinstitutional enmity remains amongst the individual actors involved. Overall, MEPs overwhelmingly saw e-transparency's principal function as enhancing and rebuilding trust in the EU in general, and in the EP in particular.

Transparency campaigners operating outside the institutions had a quite different understanding of the rationale for the use of e-transparency. Broadly speaking, they saw its value as providing a means of exposing the relationship between the institutions and the corporate sector and thus to hold the EU institutions accountable. Interestingly, these groups use the Commission's own e-transparency tools to monitor and report on this relationship. Clearly, there would seem to be a paradox where a group uses an e-transparency tool introduced to further citizen trust in the EU to identify shortcomings and present these as institutional failings: an intriguing aspect of the subject and one worthy of wider consideration.

This article has shown that different policy actors have quite different understandings of the purpose of e-transparency. For this article, with its empirical focus, it is the differences between the groups of actors that are significant. Despite these differences, however, when asked whether they considered e-transparency to be effective, all interview groups shared a common view: that limited citizen engagement with the information provided through etransparency processes reduced its effectiveness.

For MEPs, there was clear acknowledgement and some evident frustration that the etransparency tools intended to (re) build citizen trust in the EP are used chiefly by organisations 
and specialists rather than private citizens, with some MEPs suggesting that the real challenge for transparency providers is in making citizens aware of the information that is available. Commission officials, too, recognised that few citizens actually choose to access the information provided, yet expressed less frustration at this. ${ }^{20}$ This acceptance of a lack of citizen engagement does, however, seem to undermine Timmerman's view that transparency provides the means to reconnect with sceptical citizens.

For the campaigning groups, the lack of citizen engagement in the EU was a given. Indeed, several participants from campaigning groups suggested that the work of their group increases the effectiveness of the EU's e-transparency measures because the group acts as a conduit between the institutions and EU citizens. For these groups, any lack of effectiveness of etransparency is not a result of low citizen engagement but restricted group capacity, with campaigning groups having only limited resources to monitor the institutions, and often being dependent on the EU's own transparency tools to undertake this task.

Clearly then, any single e-transparency measure will have its own set of stakeholders - both advocates and critics - each of which assesses whether a measure is effective differently (Cini, 2008). Identifying the measure that captures the effectiveness of e-transparency is therefore problematic, as this will vary between actors. In this study, for example, the criteria used to assess the effectiveness of e-transparency as a means of facilitating institutional accountability, will differ from the criteria used to further public participation. To help to identify these different criteria, table 3 advances a framework for e-transparency providers to assess how the e-transparency tools can meet the differing needs of transparency users. In essence, it proposes that providers should determine the principal purpose of an e-transparency measure before it is provided. For example, if the purpose of providing information through e-transparency tools is to create greater trust in the process, a system of independent oversight should be in place to prevent inaccurate information being placed in the public domain (because this undermines the 
trust it was intended to engender). Likewise, an e-transparency measure intended to increase citizen participation should prioritise a user-friendly interface and multiple access points.

Table 3. Framework for e-transparency information providers.

\begin{tabular}{|c|c|c|c|}
\hline $\begin{array}{l}\text { Transparency } \\
\text { theme }\end{array}$ & $\begin{array}{l}\text { Underlying } \\
\text { purpose }\end{array}$ & Condition/s & Indicative indicator \\
\hline Participation & $\begin{array}{l}\text { Enhance support of } \\
\text { unelected bodies } \\
\text { through provision } \\
\text { of direct e- } \\
\text { democracy }\end{array}$ & $\begin{array}{l}\text { Ease of access - } \\
\text { User friend liness } \\
\text { of interface; } \\
\text { Multiple e- } \\
\text { participation } \\
\text { access } \\
\text { points/gate ways. }\end{array}$ & $\begin{array}{l}\text { Number of contributions to } \\
\text { public e-consultations }\end{array}$ \\
\hline Trust & $\begin{array}{l}\text { Support for } \\
\text { political } \\
\text { incumbent; Limit } \\
\text { demand for } \\
\text { devolved decision- } \\
\text { making. }\end{array}$ & $\begin{array}{l}\text { External } \\
\text { Oversight - } \\
\text { System of } \\
\text { independent } \\
\text { scrutiny to ensure } \\
\text { accuracy and } \\
\text { completeness of } \\
\text { information. }\end{array}$ & $\begin{array}{l}\text { Proportion of citizens } \\
\text { expressing trust in } \\
\text { Government/institutions - } \\
\text { measured through, e.g. } \\
\text { Eurobarometer/Asiabarometer } \\
\text { etc. }\end{array}$ \\
\hline Accountability & $\begin{array}{l}\text { Prevention of } \\
\text { malfeasance/abuse } \\
\text { of power }\end{array}$ & $\begin{array}{l}\text { Potential for } \\
\text { Sanctions - } \\
\text { Potential } \\
\text { imposition of } \\
\text { (electoral or non- } \\
\text { electoral) } \\
\text { sanctions for non- } \\
\text { compliance }\end{array}$ & $\begin{array}{l}\text { Public visibility of oversight } \\
\text { processes and of remedial } \\
\text { action taken }\end{array}$ \\
\hline Governance & $\begin{array}{l}\text { Universal } \\
\text { applicability (and } \\
\text { acceptance) of } \\
\text { regulations }\end{array}$ & $\begin{array}{l}\text { Set standards - } \\
\text { Clearly defined } \\
\text { and measurable } \\
\text { criteria of 'good } \\
\text { governance' } \\
\text { (which may be } \\
\text { externally } \\
\text { defined). }\end{array}$ & $\begin{array}{l}\text { Compliance with established } \\
\text { 'good governance' criteria }\end{array}$ \\
\hline
\end{tabular}


Although Table 3 above is based on responses of the actors and issues in this study, the model can be adapted to delineate and categorise the conflicting functions of e-transparency more widely. By doing this, transparency providers can take into account the varying requirements of the different end users in order to assess the effectiveness of e-transparency.

\section{Conclusion}

This article set out to explore how different policy actors understand the meaning of transparency and assess its effectiveness. The article argued at the outset that, in effect, the EU has multiple transparencies reflecting diverse actor interests. The research has demonstrated that the measure of the effectiveness of e-transparency varies by actor. It has shown that, collectively, the different actors involved in the policy process attribute both transparency and e-transparency with multiple benefits and both they are seen as enhancing the EU in numerous ways. Thus the e-transparency tools are considered a way of increasing citizens' trust in the institutions, of providing citizens with a means of participating in the policy process, and of providing greater institutional accountability by opening up the workings of the EU to the scrutiny of campaigning groups. This illustrates that the multiple attributes of transparency, far from being mutually reinforcing, can be contradictory. This article supports the position of those participants that argued e-transparency is a simply an ICT tool of general transparency and that both are, in and of themselves, a requirement of modern governance. The EU's multiple transparencies identified in this article are clearly a reflection of the different needs and demands of transparency stakeholders. Nonetheless, it is crucial that these differences are identified and understood and that a 'one size fits all' approach to e-transparency is avoided. Given that relatively few EU citizens currently choose to access information through the etransparency processes, those responsible for the administration of e-transparency should consider who the end user will be and how they may choose to use the information provided. It is considered that the e-transparency framework advanced in this article might go some way 
to supporting transparency providers in doing this. Finally, it is recommended that consideration be given to introducing a system of independent oversight to check the accuracy and completeness of information placed in the public domain.

\section{Acknowledgements}

The author wishes to thank all those who participated in this study and the two anonymous reviewers for their valuable comments on earlier versions of this article.

\section{Declaration of conflicting interests}

The author declares that there is no conflict of interest.

\section{Funding acknowledgement}

This work was supported by the Economic and Social Research Council [grant number ES/1026460/1].

\section{References}

Alliance for Lobbying Transparency and Ethics Regulation (2016) About us. Available at: www.alter-eu.org (accessed 8 June 2016).

Bannister F and Connolly R (2012) Forward to the past? Lessons for the future of egovernment from the story so far. Information Polity 17(3): 211-226.

Bellanca S and Vandernoot J (2014) International Public Sector Accounting Standards (IPSAS) - Implementation in the EU Member States. Journal of Modern Accounting and Auditing 10(3): 257-269.

Brandsma GJ (2013) Bending the Rules: Arrangements for Sharing Technical and Political Information between the EU Institutions. European Integration Online Papers Special Issue 1, 17: art 8 .

Brandsma GJ and Schillemans T (2013) The Accountability Cube: Measuring Accountability. Journal of Public Administration Research and Theory 23(4): 953-975.

Brandsma GJ, Heidbreder E and Mastenbroek E (2016) Accountability in the post-Lisbon European Union. International Review of Administrative Sciences 82(4): 621-637

Corporate Europe Observatory (2016) About CEO. Available at: corporateeurope.org/aboutceo (accessed 8 June 2016) 
Cini M (2008) European Commission reform and the origins of the European Transparency initiative. Journal of European Public Policy 15(5): 743-760.

Curtin D and Meijer A (2006) Does transparency strengthen legitimacy? Information Polity 11: 109-122.

Douglas, S., and Meijer. A. (2016). Transparency and Public Value - Analysing the Transparency Practices and Value Creation of Public Utilities. International Journal of Public Administration, 39 (12): 940-951.

Drew C and Nyerges T (2004) Transparency of environmental decision making: A case study of soil cleanup inside the Hanford 100 area. Journal of Risk Research 7(1): 33-71.

Egeberg M, Gornitzka A and Trondal J (2014) A not so technocratic executive: everyday interaction between the European Parliament and the Commission. West European Politics 37(1): 1-18.

Etzioni A (2010) Is Transparency the Best Disinfectant? The Journal of Political Philosophy 18(4): 389-404.

Europa (2016) About Europa. Available at: europa.eu/abouteuropa (accessed 16 June 2016).

European Coalition for Corporate Justice (2016) About us. Available at http://corporatejustice.org (accessed 16 June 2016).

European Commission (2016) Transparency Register - two year on. Available at: http://europa.eu/rapid/press-release_SPEECH-13-235_en.htm (accessed 8 June 2016).

European Court of Auditors (2017). Transparency. Available at: http://www.eca.europa.eu/en/Pages/Transparency-portal-home.aspx (accessed 5 May 2017).

European Parliament (2017) Ethics and Transparency. Available at: http://www.europarl.europa.eu/atyours ervice/en/20150201PVL00050/Ethics-andtransparency (accessed 5 May 2017).

Eurostat (2016) Information Society Statistics. Available at: ec.europa.eu/eurostat/statisticsexplained/index.php (accessed 8 June 2016).

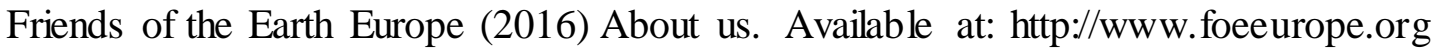
(accessed 4 May 2016).

Fox J (2010) The uncertain relationship between transparency and accountability. Development in Practice 17(4-5): 663-671.

Grimmelikhuijsen S, Porumbescu G, Hong B and Im T (2013) The effect of transparency on trust in government: A cross-national comparative experiment. Public Administration Review 73(4): 575-586. 
Harrison T and Sayogo D (2014) Transparency, participation and accountability practices in open government: A comparative study. Government Information Quarterly 31: 513-525.

Heald D (2006) Varieties of Transparency. In: Hood C and Heald D (eds) Transparency: the key to better governance? Oxford: OUP, pp. 25-43.

Héritier A (2003) Composite democracy in Europe: the role of transparency and access to information. Journal of European Public Policy 10(5): 814-833.

HM Government (2016) Improving the transparency and accountability of government and its services. Available at: www.gov.uk/government/policies/improving-the-transparencyand-accountability-of-government-and-its-services (accessed 11 May 2016).

Hood C (2006) Transparency in Historical Perspective. In: Hood C and Heald D (eds.) Transparency: The Key to Better Governance? Oxford: OUP, pp. 3-23.

Horvath R and Vasko D (2016) Central bank transparency and financial stability. Journal of financial stability 22: 45-56.

Ionescu L (2015) The role of e-government in curbing corruption in public administration. Economics, Management and Financial Markets 10(1): 48-53.

Jaeger P and Bertot J (2010) Transparency and technological change: Ensuring equal and sustained public access to government information. Government Information Quarterly 27(4): 371-376.

Mahler M and Regan P (2007) Crafting the Message: Controlling content on Agency websites. Government Information Quarterly 24(3): 505-521.

Meijer A (2009) Understanding modern transparency. International Review of Administrative Sciences 75(2): 255-269.

Meijer A (2012) Understanding the complex dynamics of transparency. Public Administration Review 73(3): 429-439.

Naurin D (2006) Transparency, publicity, accountability - the missing links. Swiss Political Science Review 12(3): 90-98.

Nolan Lord M (1995) First Report of the Committee on Standards in Public Life. London: HMSO.

Park H and Blenkinsopp $\mathbf{J}$ (2011) The roles of transparency and trust in the relationship between corruption and citizen satisfaction. International Review of Administrative Science 77(2): 254-274.

Porumbescu G and Grimmelikhuijsen S (2016) 25 years of transparency research: evidence and future directions. Public Administration Review 77(1): 32-44. 
Railiene G (2015) E-transparency as an organisational innovation in financial services: the case of Lithuania. Journal of Innovation Management 3(1): 85-103.

Scharpf F (2009) Governing in Europe: Effective and democratic? Oxford: OUP.

Schmidt V (2013) Democracy and legitimacy in the European Union revisited: Input, output and throughput. Political Studies 61:2-22.

Welch E, Hinnant C and Moon M (2005) Linking citizen satisfaction with e-government with trust in government. Journal of Public Administration Research and Theory 15(3): 371-391.

Welch E (2012) The relationship between transparent and participative government: A study of local governments in the United States. International Review of Administrative Sciences 78(1): 93-115.

Notes.

\footnotetext{
${ }^{1}$ Spring $2014 \mathrm{Global}$ attitudes survey, $71 \%$ of EU citizens agreed with the comment 'My voice does not count in the EU'; 65\% agreed with the comment 'The EU does not understand the needs of its citizens' (Pew Research Centre, 2016).

2 Simply identifying trans parency sympathisers a mongst Commission officials was problematic, as these individuals' views of e-transparency would not necessarily be representative. To address this, transparency campaigners were asked to identify their 'heroes' and 'villains' amongst officials with an interest in issues around transparency. This term had been used in a pilot interview to describe transparency advocates and opponents amongst officials and elected representatives. It was therefore used as a means of identifying participants with an interest in transparency but also to ensure a mix of views.

${ }^{3}$ COM 24, Commission [Administrative officer], Mar 2013

${ }^{4}$ COM 26, Commission [Policy officer], Apr 2013

${ }^{5}$ COM 24, Commission [Head of unit], Mar 2013

6 . Furthermore, the 1.7 million visits may not be a reliable measure of citizen engagement because those administering the site believe that it is mostly accessed by professionals, rather than the general public.

${ }^{7}$ COM 25, Commission [Policy officer], Mar 2013

8 COM 24, Commission [Head of Unit], Mar 2013

${ }^{9}$ MEP 15, ALDE member, May 2013

10 MEP22, EPP member, May 2013

11 MEP9, GUE/NGL, May 2013

12 MEP9, GUE/NGL, May 2013

13 MEP11, ALDE member, Apr 2013

14 MEP22, EPP member, May 2013

15 SOC 16 - Campaigner [European Coalition for Corporate Justice], Nov 2013

16 SOC18 - Campaigner [Access Info Europe], Feb 2014

17 SOC 14, Campaigner [Corporate Europe Observatory], Oct 2013

18 SOC 14, Campaigner [Corporate Europe Observatory], Oct 2013

19 SOC20, Campaigner [Alliance for Lobbying Transparency and Ethics Regulation], Dec 2013

${ }^{20}$ Naurin (2010) identified this as a distinction between transparency - the availability of information - and publicity- the consumption of such information.
} 